\title{
An Integrative Framework for Stakeholder Engagement Using the Basin Futures Platform
}

\author{
Jackie O'Sullivan ${ }^{1, *}$, Carmel Pollino ${ }^{1}$, Peter Taylor ${ }^{2}{ }^{\mathbb{D}}$, Ashmita Sengupta ${ }^{1}$ and Amit Parashar ${ }^{1}$ \\ 1 CSIRO Land and Water, GPO Box 1700, Canberra, ACT 2601, Australia; carmel.pollino@csiro.au (C.P.); \\ ashmita.sengupta@csiro.au (A.S.); amit.parashar@csiro.au (A.P.) \\ 2 CSIRO Data61, Sandy Bay, TAS 7005, Australia; peter.taylor@data61.csiro.au \\ * Correspondence: Jackie.osullivan@csiro.au
}

Received: 31 May 2020; Accepted: 21 August 2020; Published: 26 August 2020

\begin{abstract}
Water resources are under growing pressures globally, and better basin planning is crucial to alleviate current and future water scarcity issues. Communicating the complex interconnections and needs of natural and human systems is a significant research challenge. With advances in cyberinfrastructure allowing for new innovative approaches to basin planning, this same technology can also facilitate better stakeholder engagement. The potential benefits of using digital basin planning platforms for stakeholder engagement are immense; yet, there is limited guidance on how to best use these platforms for more effective stakeholder engagement in water-related issues and projects. We detail our digital platform, Basin Futures, and highlight the potential uses for stakeholder engagement through an integrative framework across different assessment levels. Basin Futures is a web application that is an entry-level modelling tool that aims to support rapid and exploratory basin planning globally. As a cloud-based tool, it brings together high-performance computing and large-scale global datasets to make data analysis accessible and efficient. We explore the potential use of the tool through three case studies exploring agricultural development, transboundary water-sharing agreements and allocating water for environmental flows.
\end{abstract}

Keywords: river basin planning; digital platforms; stakeholder engagement; integrated water resource management

\section{Introduction}

Water resources are under growing pressures globally, with nearly $80 \%$ of the world's population are exposed to a high level of threats stemming from water insecurity [1-3]. Water insecurity is manifested through physical shortages, failure of institutions or lack of infrastructure [4]. Shortages in water impact on people's health, livelihoods, ecosystems and the ability to produce food [4-6]. It also impacts a nation's ability to achieve Sustainable Development Goals. Water resource issues are driven by inter-dependencies between hydrological, social, economic and ecological needs in river, lake and aquifer basins. Communicating the complex interconnections and needs of natural and human systems is a significant research challenge [7]. Better water planning is crucial, and if water management habits do not change, the global demand for water could increase by $50 \%$ by 2030 [8]. In the face of climate change, population growth, economic development and increased water demand, these inter-dependencies require more integrated approaches to developing and managing water and land resources [9].

The use of technology has advanced significantly in the last 20 years. The expansion in the capabilities of computing power and cyberinfrastructure provides a new approach to address water resource issues and engagement with society [10]. Complex interconnections and unprecedented changes between natural and human systems are recognised as a significant research challenge [7]. 
There is a growing need for long-term strategic basin planning that crosses sectors and jurisdictions to encapsulate changes in water resources. Innovative and technologically advanced solutions are required to manage water resources and facilitate stakeholder engagement in an accountable and non-discriminatory manner $[7,10]$.

There are numerous economic, environmental and social benefits to be gained from effectively engaging with stakeholders at the basin level in water policies and projects [11-14]. Stakeholder engagement is often undertaken in an ad-hoc and ineffective manner. Implementing a digital stakeholder engagement strategy can dramatically improve stakeholder participation and outcomes [15-17]. The use of digital platforms assists in providing a more transparent and authentic stakeholder engagement program and therefore improving the likelihood of engagement. Digital tools provide accountable and transparent information to reassure the public of the evidence base underpinning water management plans and proposals [18]. This accountability and ability to reach more participants in a non-discriminatory manner aligns with the principles of good water governance of Integrated Water Resource Management (IWRM) [3]. New cloud technologies for the data-intensive world can provide the ability to analyse and integrate the vast and complex historic and current environmental information to manageable levels [19]. Cloud technology can help to visualise issues and options to make it easier to gain creative insights and build collaborations with stakeholders [19].

Alleviating water security challenges requires basic information on water resources [20]. This information includes knowing how much water is available, where it is distributed and how it will change under scenarios of development and climate change. Data and models are often used to address these questions. However, data are fragmented, difficult to access and process and models require significant expense, time to develop, and advanced capability and capacity to use. As a result, it can be difficult and expensive to support the basic information needs to overcome water scarcity and for stakeholders to speak a common language. Basin Futures was developed in response to our experiences working in Australia and internationally on potential water resource developments and complex water management issues. During this time, we noticed users spent a lot of time in data discovery, transformation and understanding complex modelling software. This resulted in limited uptake and the use of tools which limited the level of engagement and participation of stakeholders in water-related issues. We detail our digital observatory platform, Basin Futures, and highlight the potential uses for stakeholder engagement through an integrative framework. We explore the potential use of the tool through three case studies exploring agricultural development, transboundary water-sharing agreements and allocating water for environmental flows.

\section{The Basin Futures Platform}

The Basin Futures platform was designed based on the needs expressed by catchment managers, policymakers, environmental groups, and scientists. It is designed to lower the barrier to entry for conducting initial assessments of basin water resources and explore future development scenarios. Basin Futures leverages existing data (global and local) to empower decision-makers to understand their opportunities and constraints in managing water resources [21]. The platform integrates global data with models, all packaged in a web application with readily available cloud processing. This reduces costs on multiple fronts: data integration, model setup and integration, and infrastructure. This setup allows quick range-finding scenarios to be run, providing an explorative tool to aid water resource planning discussion. Basin Futures currently has two main modelling components: rainfall-runoff via GR4J [22] to generate the runoff in a basin, and a custom-built reach model for undertaking water management and transfer activities such as water storage, hydropower generation, routing of flows through the basin, demands/consumption and crop modelling (Figure 1). Basin water balance is produced on a daily basis but lumped monthly, with outputs able to be reported on a monthly or annual scale. Future scenarios are able to be run to explore climate change and changing population scenarios. Basin Futures uses climate scenarios based on The Inter-Sectoral Impact Model Inter-comparison Project (ISIMIP) outputs [23]. Enabling users to plan for climate resilient basins by assessing the 
potential changes in the quantity and timing of runoff, precipitation and streamflow based on multiple future climate scenarios.

\section{Conceptual Reach Model}

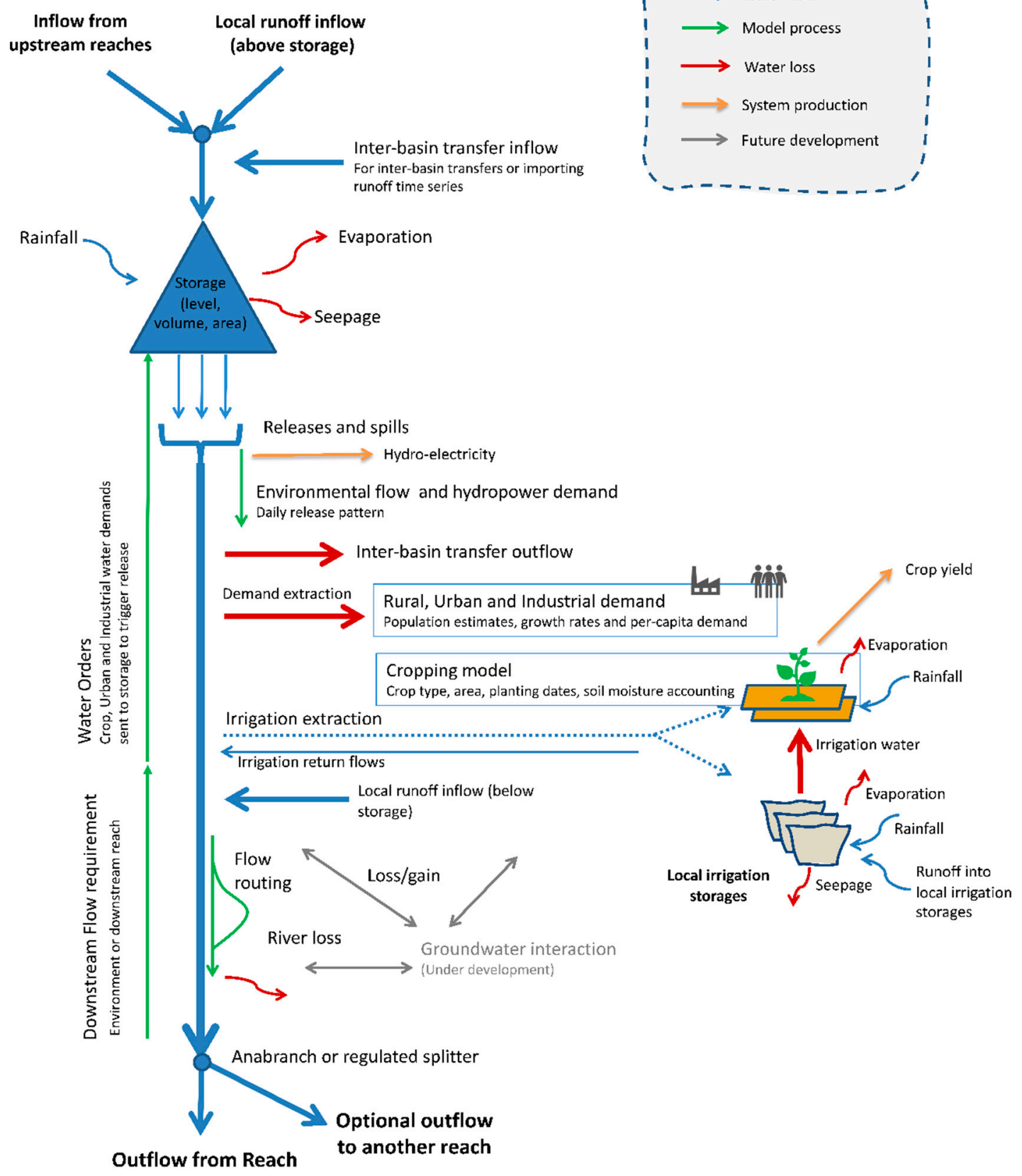

Figure 1. Conceptualisation of the reach model engine underlying Basin Futures.

Our approach focusses on three aspects: global application, easy development of scenarios, and a lower barrier to entry. These key aspects are where Basin Futures differs from existing systems, such as those focused on specific water management areas such as flood forecasting [24,25]. Our approach is similar to a recent web implementation of the Soil and Water Assessment Tool (SWAT) Online [26]; however, we provide scenario development and result assessment. Basin Futures supports users with a robust yet simple modelling framework and can provide a pathway to more sophisticated products through export capabilities. The model workflow provides a consistent and repeatable process of 
basin water assessments for any basin across the globe (Figure 2). Basin Futures provides an enabling environment for planning, cooperation and participation in water management.

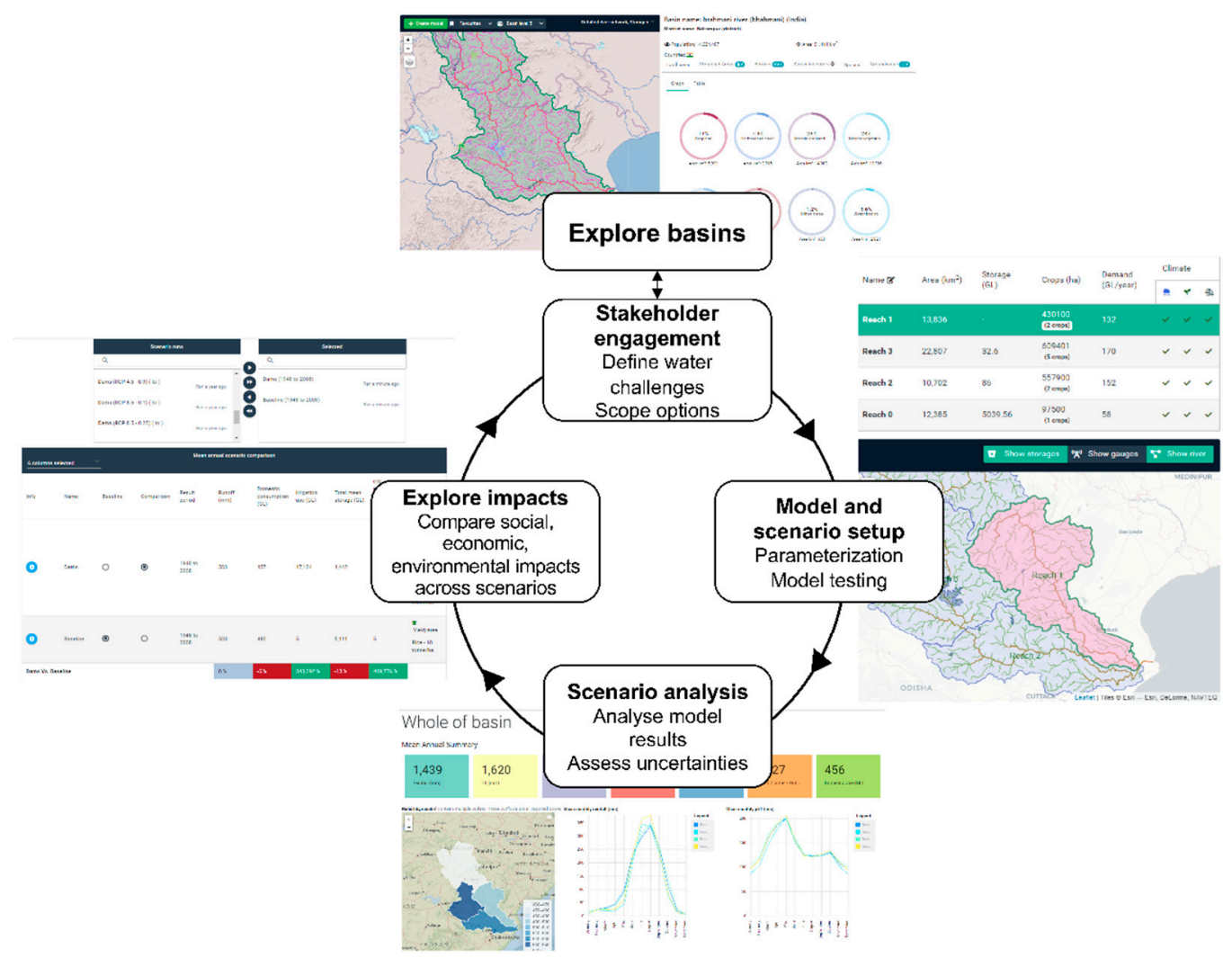

Figure 2. User workflow within Basin Futures.

\section{Stakeholder Engagement: Encouraging and Scaling Participation in the Basin Planning Process}

Water-related developments or changes require collaboration between a wide range of stakeholder groups from landholders to scientists to policymakers. Depending on the complexity, scale and impacts of the project, the level of stakeholder engagement can range from merely providing information to active partnerships and collaboration. For stakeholders to fully engage, an enabling environment for effective, fit-for-purpose and outcome-oriented stakeholder engagement should be provided [27]. Digital platforms can be used as a common platform between stakeholders to contribute data, knowledge and understanding and visualisation of an issue $[7,10]$.

Digital platforms can be used to reach a wider stakeholder audience to encourage participation in water-related planning and development. Digital platforms can be used to invite the entire population of a basin to participate in consultations on a specific and well-defined issue or in events or actions which have an indirect impact on the basin's water resources management [27]. The use of digital platforms can increase access, integration and exploitation of environmental data and knowledge by scientific and end-user communities $[15-17,19]$. This is particularly relevant for cloud-based approaches where services (i.e., computing power and data storage) are also available to users which provide greater accessibility, efficiency and transparency to stakeholders.

The Basin Futures platform can be used to make scaling assessment areas and stakeholder engagement easier through user-friendly interfaces, intuitive workflow and the ability to move between multiple scales of observation (micro, meso and macro) and modelling within one platform. This can facilitate collaboration between landholders, scientists and policymakers through the transfer of knowledge and data from small-scale drainage basins to larger aggregates or transboundary basins, contributing to well-informed decisions and policies (Figure 3). 


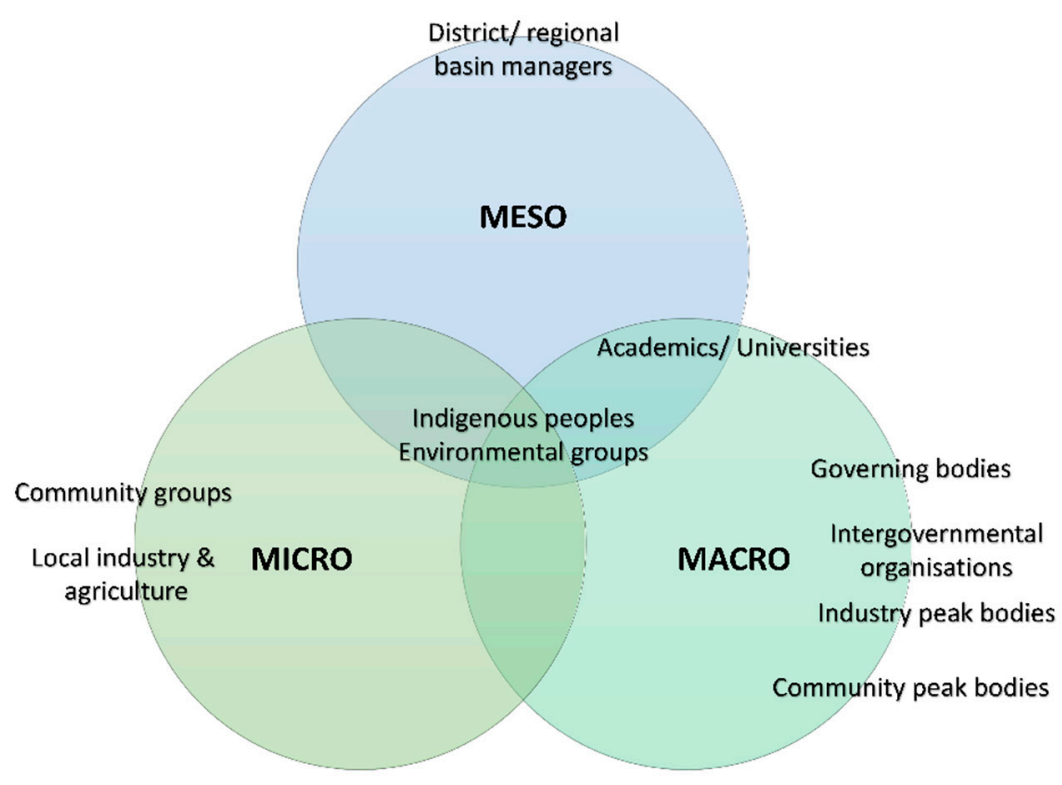

Figure 3. Representation of macro-, meso- and micro-level stakeholder groups.

\section{Framework for Integrative Stakeholder Engagement}

Despite the immense potential for digital platforms to be used for stakeholder engagement, there are limited guiding frameworks for how they should be implemented in conjunction with best practice IWRM principles. We present our framework for stakeholder engagement and collaboration on water-related issues and projects using digital platforms (Figure 4). The framework was generated based on IWRM principles and our collective experience of engaging with stakeholders on water resource developments and complex water management issues We then apply this framework to three case studies using the Basin Futures platform. The framework comprises of five main steps. The first is to identify the problem or issue at hand, for example, will the water supply be sufficient for future demands of a particular basin. The second step is to define the problem, identify the stakeholders, define goals and constraints and identify alternatives. The third step is the collaborate with stakeholders and explore options within the digital platform, including determining the current water balance and future changes through multiple scenarios. The fourth is to evaluate options explored and their environmental, economic and social impacts. The final step is to decide on an option or identify alternatives.

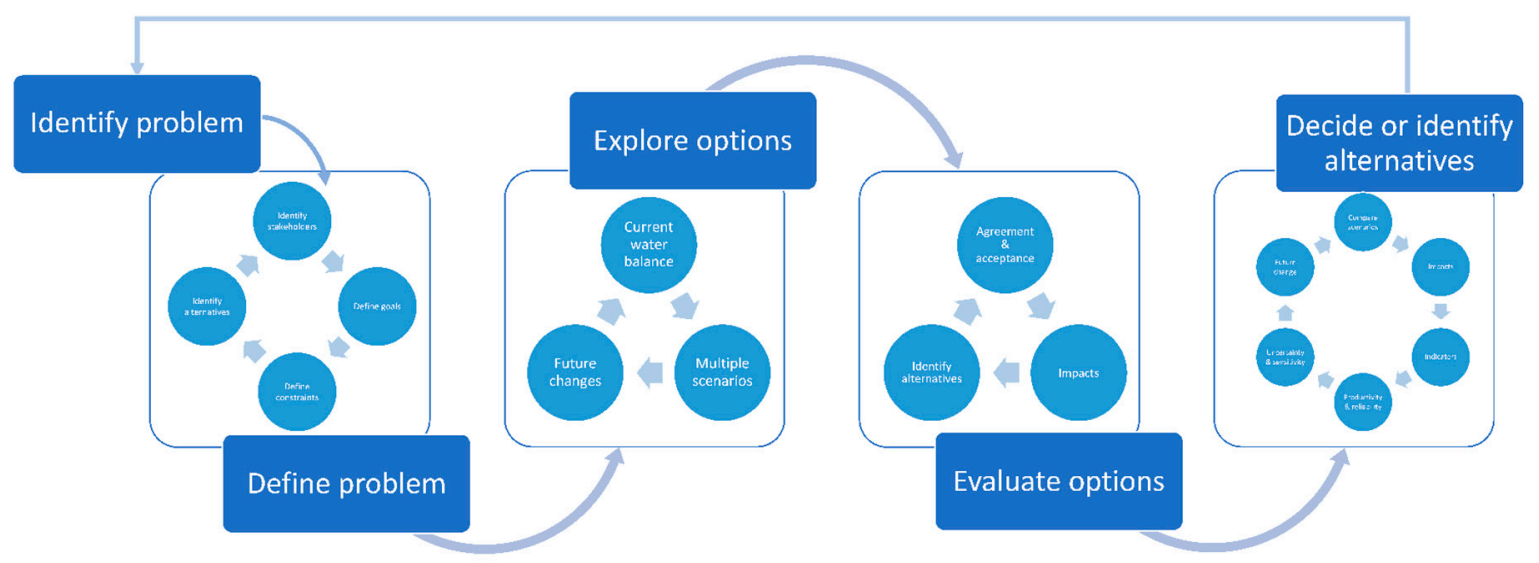

Figure 4. Framework for stakeholder engagement and collaboration on water-related issues and projects using digital platforms. 


\section{Case Study Applications of Basin Futures}

\subsection{Case Study 1: Stakeholder Engagement in Agricultural Development Projects}

The world's population is projected to increase by $35 \%$ by 2050 , which will require a $70-100 \%$ rise in food production given projected trends in diets, consumption, and income [6,28,29]. Over three-quarters of the projected increased population live in developing countries and in regions that already lack the capacity to produce enough food [30]. Increased food production can be achieved by increasing crop yields on existing farmland through better sustainable management practices or expanding crop production areas. Sustainable development of agricultural resources requires resolution and incorporation of diverse stakeholder values and interests. Collaboration and effective communication between local-scale farmers, governing bodies and research organisations can enable an efficient agriculture production system to be designed.

The Basin Futures platform can be used to explore and collaborate on agricultural development scenarios. The platform can be parameterised to incorporate current agriculture demands on an annual basis and forecast potential expansions, intensification and changes to agricultural systems as well as changes in water supply caused by other factors such as climate change. Basin Futures can assess the temporal reliability and production values of various agricultural scenarios and determine the impact on water resources and the environment. We selected the Purari Basin in Papua New Guinea (PNG) to demonstrate a potential stakeholder engagement strategy regarding agricultural development using the Basin Futures platform.

\subsubsection{The Problem—Agricultural Development in the Purari Basin, Papua New Guinea}

Agriculture plays a vital role in the Papua New Guinean economy. It employs $\sim 50 \%$ of the national workforce, which generates $15 \%$ of gross domestic product (GDP) [31]. Despite its importance, agricultural productivity in PNG is generally low due to inadequate infrastructure and access to essential knowledge and farm inputs. It is estimated that $30 \%$ of the land is suitable for agriculture, yet only $2.2 \%$ is used commercially [31]. Papua New Guinea aims to enhance agricultural productivity, the scale of production, market access and income generation [31]. We use the Purari Basin as an example of a potential PNG basin to undergo agricultural development. The Purari Basin is located in the district of Chuave, Papua New Guinea. Purari Basin has an area of 33,080 km and an approximate population of 1.9 million people. The Basin experiences low water stress, but droughts and floods occur regularly.

\subsubsection{Understanding the Problem}

Papua New Guinea is a rural society with the majority of the population living in traditional communities [31]. There is limited commercial agriculture, and most produce is from small-scale, family-run farms. Small-scale farmers would provide invaluable insights into crop types, planting dates, expected yields and seasonal influences that would provide validation of the current agricultural baseline along with calibration of projected developments. The Purari Basin is home to several protected areas such as the Siwi-Utame Wildlife Management Area. Therefore, any major development is likely to require approval and engagement from indigenous peoples and national governing bodies such as the Conservation and Environment Protection Authority. Potential agricultural development would require a collaborative approach to stakeholder engagement across multiple assessment levels (Table 1). 
Table 1. Stakeholder model inputs, contributions and outputs at various assessment levels within the Purari Basin. Directions of arrows indicate increases $(\uparrow)$ and decreases $(\downarrow)$ of outputs.

\begin{tabular}{|c|c|c|c|c|}
\hline Stakeholders & Model Inputs & $\begin{array}{l}\text { Assessment } \\
\text { Level }\end{array}$ & Contribution & Outputs \\
\hline Local farmers & $\begin{array}{l}\text { Crop types and varieties, } \\
\text { crop prices, planting date, } \\
\text { maximum yields, cropping } \\
\text { intensity, irrigated supply } \\
\text { efficiency, soil characteristics, } \\
\text { planting areas, fallow } \\
\text { characteristics, suitability of } \\
\text { area for agriculture }\end{array}$ & Micro & $\begin{array}{l}\text { Local knowledge, } \\
\text { empowerment, } \\
\text { concerns and } \\
\text { aspirations }\end{array}$ & $\begin{array}{c}\uparrow \text { Knowledge } \\
\uparrow \text { Accuracy } \\
\uparrow \text { Participation } \\
\uparrow \text { Stakeholder } \\
\text { empowerment and } \\
\text { equity } \\
\uparrow \text { Likelihood of } \\
\text { agreement } \\
\downarrow \text { Likelihood of conflict }\end{array}$ \\
\hline Indigenous peoples & $\begin{array}{l}\text { Suitability of area for } \\
\text { agriculture }\end{array}$ & Micro/Meso/Ma & $\begin{array}{l}\text { Local knowledge, } \\
\text { cro oultural awareness } \\
\text { culat }\end{array}$ & $\begin{array}{c}\uparrow \text { Knowledge } \\
\uparrow \text { Awareness } \\
\uparrow \text { Inclusiveness } \\
\uparrow \text { Participation } \\
\uparrow \text { Stakeholder } \\
\text { empowerment and } \\
\text { equity } \\
\uparrow \text { Likelihood of } \\
\text { agreement } \\
\downarrow \text { Likelihood of conflict }\end{array}$ \\
\hline $\begin{array}{l}\text { Environmental } \\
\text { groups }\end{array}$ & $\begin{array}{l}\text { Suitability of area for } \\
\text { agriculture }\end{array}$ & Micro/Meso/Ma & $\begin{array}{l}\text { Local/national } \\
\text { cro knowledge, } \\
\text { expertise, concerns }\end{array}$ & $\begin{array}{c}\uparrow \text { Knowledge } \\
\uparrow \text { Awareness } \\
\uparrow \text { Inclusiveness } \\
\uparrow \text { Participation } \\
\uparrow \text { Stakeholder } \\
\text { empowerment and } \\
\text { equity } \\
\uparrow \text { Likelihood of } \\
\text { agreement } \\
\downarrow \text { Likelihood of conflict }\end{array}$ \\
\hline Academics & $\begin{array}{l}\text { Crop types, crop prices, } \\
\text { maximum yields, cropping } \\
\text { intensity, irrigated supply } \\
\text { efficiency, suitability of area } \\
\text { for agriculture }\end{array}$ & Meso/Macro & $\begin{array}{l}\text { Knowledge, } \\
\text { evidence-based } \\
\text { research }\end{array}$ & $\begin{array}{c}\uparrow \text { Knowledge } \\
\uparrow \text { Accuracy } \\
\uparrow \text { Robustness }\end{array}$ \\
\hline Local industry & $\begin{array}{c}\text { Crop types, crop prices, } \\
\text { maximum yields, cropping } \\
\text { intensity, irrigated supply } \\
\text { efficiency, suitability of area } \\
\text { for agriculture }\end{array}$ & Micro/Meso & $\begin{array}{l}\text { Local concerns, } \\
\text { knowledge }\end{array}$ & $\begin{array}{c}\uparrow \text { Knowledge } \\
\uparrow \text { Awareness } \\
\uparrow \text { Inclusiveness } \\
\uparrow \text { Participation } \\
\uparrow \text { Stakeholder } \\
\text { empowerment and } \\
\text { equity } \\
\uparrow \text { Likelihood of } \\
\text { agreement } \\
\downarrow \text { Likelihood of conflict }\end{array}$ \\
\hline $\begin{array}{c}\text { States/district } \\
\text { officials/regional } \\
\text { basin managers }\end{array}$ & $\begin{array}{l}\text { Current storages, crop types, } \\
\text { maximum yields, cropping } \\
\text { intensity, irrigated supply } \\
\text { efficiency, planting areas, } \\
\text { suitability of area for } \\
\text { agriculture }\end{array}$ & Meso & $\begin{array}{l}\text { Facilitating efforts, } \\
\text { coordinating }\end{array}$ & $\begin{array}{c}\uparrow \text { Awareness } \\
\uparrow \text { Inclusiveness } \\
\uparrow \text { Participation } \\
\uparrow \text { Stakeholder } \\
\text { empowerment and } \\
\text { equity } \\
\uparrow \text { Likelihood of } \\
\text { agreement } \\
\downarrow \text { Likelihood of conflict }\end{array}$ \\
\hline
\end{tabular}


Table 1. Cont.

\begin{tabular}{|c|c|c|c|c|}
\hline Stakeholders & Model Inputs & $\begin{array}{l}\text { Assessment } \\
\text { Level }\end{array}$ & Contribution & Outputs \\
\hline $\begin{array}{l}\text { Government } \\
\text { bodies (National } \\
\text { Department of } \\
\text { Agriculture and } \\
\text { Livestock) }\end{array}$ & $\begin{array}{l}\text { Current storages, potential } \\
\text { storages, crop prices, } \\
\text { irrigated supply efficiency, } \\
\text { planting areas, suitability of } \\
\text { area for agriculture, } \\
\text { nutritional values }\end{array}$ & Macro/Meso & $\begin{array}{c}\text { Facilitating, } \\
\text { funding, regulation }\end{array}$ & $\begin{array}{c}\uparrow \text { Awareness } \\
\uparrow \text { Inclusiveness } \\
\uparrow \text { Participation } \\
\uparrow \text { Stakeholder } \\
\text { empowerment and } \\
\text { equity } \\
\uparrow \text { Likelihood of } \\
\text { agreement } \\
\downarrow \text { Likelihood of conflict }\end{array}$ \\
\hline $\begin{array}{l}\text { Community peak } \\
\text { bodies (i.e., Pacific } \\
\text { Island Farmers } \\
\text { Organisation } \\
\text { Network) }\end{array}$ & $\begin{array}{l}\text { Crop prices, planting areas, } \\
\text { suitability of area for } \\
\text { agriculture }\end{array}$ & Macro/Meso & $\begin{array}{l}\text { Stakeholder } \\
\text { representation, } \\
\text { communication }\end{array}$ & $\begin{array}{c}\uparrow \text { Awareness } \\
\uparrow \text { Likelihood of } \\
\text { agreement } \\
\downarrow \text { Likelihood of conflict }\end{array}$ \\
\hline $\begin{array}{l}\text { Industry peak } \\
\text { bodies }\end{array}$ & $\begin{array}{c}\text { Crop prices, planting areas, } \\
\text { suitability of area for } \\
\text { agriculture }\end{array}$ & Macro/Meso & $\begin{array}{l}\text { Regulation, } \\
\text { communication }\end{array}$ & $\begin{array}{c}\uparrow \text { Awareness } \\
\uparrow \text { Likelihood of } \\
\text { agreement } \\
\downarrow \text { Likelihood of conflict }\end{array}$ \\
\hline $\begin{array}{l}\text { International } \\
\text { agribusinesses }\end{array}$ & Crop prices, crop types & Macro & $\begin{array}{l}\text { Global markets } \\
\text { influence local } \\
\text { farming practices } \\
\text { (e.g., planting } \\
\text { decisions) }\end{array}$ & $\begin{array}{c}\uparrow \text { Awareness } \\
\uparrow \text { Likelihood of } \\
\text { agreement } \\
\downarrow \text { Likelihood of conflict }\end{array}$ \\
\hline
\end{tabular}

\subsubsection{Exploring and Evaluating Options with a Common Vision}

Through the collaboration and use of the Basin Futures digital platform, a common vision for agricultural development could be attained by developing relevance and direction. Enabling cooperative, best-practice and efficient agriculture production systems to be designed. Channelling the efforts and knowledge of all stakeholders into the one platform can increase common understanding and agreements on priorities achieved through a fully inclusive, transparent and participatory process.

\subsection{Case Study 2: Negotiating Water-Sharing Agreements}

Water issues, hydrological boundaries and development impacts cut across administrative frontiers. Well-informed water management decisions and policies require effective communication and a shared understanding of the issue at hand between stakeholders. Communication and understanding between stakeholders can be difficult to achieve, especially in transboundary or politically contentious basins. Digital tools that are objective, transparent and cater to a range of abilities can pave the way forward to understanding issues and effective communication between stakeholder groups.

The purpose of Basin Futures is to digitally transform engagement processes and make accessible information and evidence for the majority, hence giving people voice and the ability to engage with the evidence for themselves and explore scenarios and their alternatives rather than just relying on more prescribed information. The use of digital platforms that can take into account global scale hydrological changes such as climate change and local scale water issues and developments and create tangible dialogues for action at appropriate national, regional, and local scales is a key to future stakeholder engagement processes. We selected the Mahanadi Basin to demonstrate a potential stakeholder engagement strategy for negotiating water-sharing agreements between the states of Chhattisgarh and Odisha using the Basin Futures platform.

\subsubsection{The Problem—Water Sharing in the Mahanadi Basin, India}

The Mahanadi Basin in India is home to 36 million people. The Mahanadi River begins in the state of Chhattisgarh and flows through to the state of Odisha. The river is essential for intensive 
agriculture in the region, not only for irrigation but for extensive fertile soil the river deposits along the $858 \mathrm{~km}$ river course. The construction of the large Hirakud Dam has greatly altered the flow regime and extent of flooding that occurs in the region. Water sharing practices in the Mahanadi Basin have been a source of conflict between the Indian States of Chhattisgarh and Odisha. The two states are in dispute over the construction of allegedly illegal barrages within the respective states that are damaging the ecological integrity of the river. The states also disagree on the use of the Hirakud Dam and the catchment area share each state has of the reservoir.

\subsubsection{Understanding the Problem}

The Mahanadi Basin is essential for agriculture, industry, drinking water and the environment. Negotiating water-sharing agreements in this Basin would require an objective tool that would foster cooperation and partnership between contrasting stakeholder groups and governing bodies. The use of the Basin Futures platform could provide an easy exchange of information based on a common agenda across many production systems and ecological zones. Cooperation could be further facilitated through clear mechanisms and lines of communication. All efforts and resources of stakeholders should be channelled in that direction, guided by common understanding and agreements on priorities achieved through fully inclusive and participatory processes (Table 2). Furthermore, the use of the same datasets, methods and modelling platform would allow for unbiased dialogues and solutions to be created.

Table 2. Stakeholder model inputs, contributions and outputs at various assessment levels within the Mahanadi Basin. Directions of arrows indicate increases $(\uparrow)$ and decreases $(\downarrow)$ of outputs.

\begin{tabular}{|c|c|c|c|c|}
\hline Stakeholders & Model Inputs & $\begin{array}{l}\text { Assessment } \\
\text { Level }\end{array}$ & Contribution & Outputs \\
\hline Local farmers & $\begin{array}{l}\text { Irrigated demands, timing of } \\
\text { demands }\end{array}$ & Micro/Meso & $\begin{array}{l}\text { Local knowledge, } \\
\text { concerns, inputs }\end{array}$ & $\begin{array}{c}\uparrow \text { Knowledge } \\
\uparrow \text { Participation } \\
\uparrow \text { Likelihood of } \\
\text { agreement } \\
\downarrow \text { Likelihood of conflict }\end{array}$ \\
\hline Indigenous peoples & Cultural values & $\begin{array}{l}\text { Micro/Meso/ } \\
\text { Macro }\end{array}$ & $\begin{array}{l}\text { Local knowledge, } \\
\text { cultural awareness }\end{array}$ & $\begin{array}{c}\uparrow \text { Knowledge } \\
\uparrow \text { Participation } \\
\uparrow \text { Awareness } \\
\uparrow \text { Inclusiveness } \\
\uparrow \text { Likelihood of } \\
\text { agreement } \\
\downarrow \text { Likelihood of conflict }\end{array}$ \\
\hline $\begin{array}{l}\text { Environmental } \\
\text { groups }\end{array}$ & $\begin{array}{l}\text { Environmental values and } \\
\text { requirements }\end{array}$ & $\begin{array}{l}\text { Micro/Meso/ } \\
\text { Macro }\end{array}$ & $\begin{array}{l}\text { Local/national } \\
\text { knowledge, } \\
\text { concerns, } \\
\text { awareness }\end{array}$ & $\begin{array}{c}\uparrow \text { Knowledge } \\
\uparrow \text { Participation } \\
\uparrow \text { Awareness } \\
\uparrow \text { Inclusiveness } \\
\uparrow \text { Likelihood of } \\
\text { agreement } \\
\downarrow \text { Likelihood of conflict }\end{array}$ \\
\hline Academics & $\begin{array}{l}\text { Evidence-based water } \\
\text { transfer partitioning }\end{array}$ & Meso/Macro & $\begin{array}{l}\text { Knowledge, } \\
\text { evidence-based } \\
\text { research, range } \\
\text { finding, system } \\
\quad \text { sensitivity }\end{array}$ & $\begin{array}{c}\uparrow \text { Knowledge } \\
\uparrow \text { Accuracy } \\
\uparrow \text { Robustness } \\
\uparrow \text { Stakeholder } \\
\text { empowerment and } \\
\text { equity } \\
\uparrow \text { Likelihood of } \\
\text { agreement } \\
\downarrow \text { Likelihood of conflict } \\
\downarrow \text { Unintended trade-offs } \\
\text { in water benefits }\end{array}$ \\
\hline
\end{tabular}


Table 2. Cont.

\begin{tabular}{|c|c|c|c|c|}
\hline Stakeholders & Model Inputs & $\begin{array}{l}\text { Assessment } \\
\text { Level }\end{array}$ & Contribution & Outputs \\
\hline Local industry & Water demands and timing & Micro/Meso & $\begin{array}{l}\text { Local concerns, } \\
\text { knowledge, inputs }\end{array}$ & $\begin{array}{c}\uparrow \text { Knowledge } \\
\uparrow \text { Participation } \\
\uparrow \text { Likelihood of } \\
\text { agreement } \\
\downarrow \text { Likelihood of conflict }\end{array}$ \\
\hline $\begin{array}{c}\text { States/district } \\
\text { officials/regional } \\
\text { basin managers }\end{array}$ & $\begin{array}{l}\text { Current demands, future } \\
\text { demands, water allocation } \\
\text { requirements }\end{array}$ & Meso & $\begin{array}{l}\text { Facilitating efforts, } \\
\text { coordinating, } \\
\text { communication, } \\
\text { awareness, } \\
\text { prioritisation, } \\
\text { range finding, } \\
\text { alternative } \\
\text { pathways, system } \\
\text { sensitivity }\end{array}$ & $\begin{array}{c}\uparrow \text { Awareness } \\
\uparrow \text { Inclusiveness } \\
\uparrow \text { Participation } \\
\uparrow \text { Stakeholder } \\
\text { empowerment and } \\
\text { equity } \\
\uparrow \text { Likelihood of } \\
\text { agreement } \\
\downarrow \text { Likelihood of conflict } \\
\downarrow \text { Unintended trade-offs } \\
\text { in water benefits }\end{array}$ \\
\hline $\begin{array}{l}\text { Government } \\
\text { bodies }\end{array}$ & $\begin{array}{l}\text { Current demands, future } \\
\text { demands, water allocation } \\
\text { requirements }\end{array}$ & Macro/Meso & $\begin{array}{l}\text { Facilitating efforts, } \\
\text { coordinating, } \\
\text { communication, } \\
\text { awareness, } \\
\text { prioritisation, } \\
\text { range finding, } \\
\text { alternative } \\
\text { pathways, system } \\
\text { sensitivity }\end{array}$ & $\begin{array}{c}\uparrow \text { Awareness } \\
\uparrow \text { Inclusiveness } \\
\uparrow \text { Participation } \\
\uparrow \text { Stakeholder } \\
\text { empowerment and } \\
\text { equity } \\
\uparrow \text { Likelihood of } \\
\text { agreement } \\
\downarrow \text { Likelihood of conflict } \\
\downarrow \text { Unintended trade-offs } \\
\text { in water benefits }\end{array}$ \\
\hline $\begin{array}{l}\text { Environmental } \\
\text { peak bodies (i.e., } \\
\text { World Wildlife } \\
\text { Foundation) }\end{array}$ & $\begin{array}{l}\text { Environmental values and } \\
\text { requirements }\end{array}$ & Macro/Meso & $\begin{array}{l}\text { Local/national } \\
\text { knowledge, } \\
\text { concerns, } \\
\text { awareness }\end{array}$ & $\begin{array}{c}\uparrow \text { Knowledge } \\
\uparrow \text { Robustness } \\
\uparrow \text { Accuracy } \\
\uparrow \text { Awareness } \\
\uparrow \text { Inclusiveness } \\
\uparrow \text { Participation } \\
\uparrow \text { Support } \\
\uparrow \text { Likelihood of } \\
\text { agreement } \\
\downarrow \text { Likelihood of conflict }\end{array}$ \\
\hline $\begin{array}{l}\text { Industry peak } \\
\text { bodies }\end{array}$ & Export demands & Macro/Meso & $\begin{array}{l}\text { Regulation, } \\
\text { communication }\end{array}$ & $\begin{array}{c}\uparrow \text { Awareness } \\
\uparrow \text { Likelihood of } \\
\text { agreement } \\
\downarrow \text { Likelihood of conflict }\end{array}$ \\
\hline $\begin{array}{l}\text { Intergovernmental } \\
\text { organisations }\end{array}$ & $\begin{array}{l}\text { Evidence-based water } \\
\text { transfer partitioning }\end{array}$ & Macro & $\begin{array}{l}\text { Regulation, } \\
\text { communication }\end{array}$ & $\begin{array}{c}\uparrow \text { Awareness } \\
\uparrow \text { Likelihood of } \\
\text { agreement } \\
\downarrow \text { Likelihood of conflict }\end{array}$ \\
\hline
\end{tabular}

\subsection{Case Study 3: Environmental Flows}

Water resources produced by healthy ecosystems provide livelihood support for millions of people; this support is often extremely critical and essential for developing regions. River flow regimes are regarded to be the primary drivers of riverine and floodplain wetland ecosystems [32-34]. The flow regime is a major determinant of both biotic and abiotic components of a river system. Alteration of the natural flow regime can have serious consequences on the ecological sustainability of rivers and their associated floodplain wetlands [32,34]. The environment needs water to sustain itself, but in the water allocation decision-making process, the needs of the environment are often neglected [35]. If too much water is allocated to other sectors, the impacts on ecosystems can be devastating. A balance needs to be struck between people's direct water needs for domestic use, industry and agriculture and their indirect needs, through the numerous and unquantified goods and services provided by 
functioning ecosystems [36]. Stakeholder engagement and consensus in environmental flows can be difficult to obtain due to a lack of clarity on the issue, perceived non-transparent information and complexities of interacting perspectives.

The Basin Futures platform can be used to explore and collaborate on environmental flow scenarios. The platform is objective, transparent and allows users to run their own models, interpret results and form their own opinions instead of relying on more prescribed information. The platform can be used to range find and balance the inter-dependencies between hydrological, social, economic and ecological needs in river, lake and aquifer basins. We have selected the Pangani Basin in Tanzania, Africa, to demonstrate a potential stakeholder engagement strategy for environmental flows using the Basin Futures platform.

\subsubsection{The Problem-Environmental Flows in the Pangani Basin, Tanzania}

The Pangani River Basin in East Africa has a population of 2.6 million people. The Pangani River begins as a series of small streams near Mount Kilimanjaro and passes through the arid Masai Steppe before reaching its estuary and the Indian Ocean. Along its $500 \mathrm{~km}$ course, the Pangani River is a lifeline for biodiversity, people, and industry, and is fundamental to the economic development of the region. The Basin is home to Kilimanjaro National Park, a listed World Heritage Site with extensive biodiversity values. The Pangani Basin experiences medium to high water stress with a high flood occurrence. The Basin contains several critically endangered terrestrial and aquatic species.

\subsubsection{Understanding the Problem}

The Pangani Basin has widespread biodiversity values but is also used extensively for agriculture, industry and hydropower. Agreement on allocating water for the environment would have to include contrasting stakeholder groups with different perspectives and values. Consensus on how much, when and the variability of water provided to the environment would require a mechanism for negotiation using processes that enable the interests of traditionally more powerful water users and less powerful sectors to be reconciled [37,38]. Environmental flows must have clear objectives and scenarios built on multi-stakeholder consensus. Scientists can provide expert advice on how river basins change under various flow conditions, but it is the stakeholders who can say what the river is used for and how much water they need. The Basin Futures platform can be used to reconcile different stakeholder views and inputs to evaluate how ecology, economic costs and benefits across sectors and social equity respond to alternate river flow scenarios at multiple assessment levels (Table 3).

Table 3. Stakeholder model inputs, contributions and outputs at various assessment levels within the Pangani River Basin. Directions of arrows indicate increases $(\uparrow)$ and decreases $(\downarrow)$ of outputs.

\begin{tabular}{|c|c|c|c|c|}
\hline Stakeholders & Model Inputs & $\begin{array}{l}\text { Assessment } \\
\text { Level }\end{array}$ & Contribution & Outputs \\
\hline Local farmers & $\begin{array}{l}\text { Irrigated demands, timing of } \\
\text { demands }\end{array}$ & Micro/Meso & $\begin{array}{l}\text { Local knowledge, } \\
\text { concerns, inputs }\end{array}$ & $\begin{array}{c}\uparrow \text { Knowledge } \\
\uparrow \text { Participation } \\
\uparrow \text { Likelihood of } \\
\text { agreement } \\
\downarrow \text { Likelihood of conflict }\end{array}$ \\
\hline Indigenous peoples & $\begin{array}{l}\text { Environmental values, flow } \\
\text { timing and requirements }\end{array}$ & $\begin{array}{l}\text { Micro/Meso/ } \\
\text { Macro }\end{array}$ & $\begin{array}{l}\text { Local knowledge, } \\
\text { cultural awareness, } \\
\text { environmental and } \\
\text { cultural inputs, } \\
\text { prioritisation }\end{array}$ & $\begin{array}{c}\uparrow \text { Knowledge } \\
\uparrow \text { Robustness } \\
\uparrow \text { Accuracy } \\
\uparrow \text { Awareness } \\
\uparrow \text { Inclusiveness } \\
\uparrow \text { Participation } \\
\uparrow \text { Stakeholder } \\
\text { empowerment and } \\
\text { equity } \\
\uparrow \text { Likelihood of } \\
\text { agreement } \\
\downarrow \text { Likelihood of conflict }\end{array}$ \\
\hline
\end{tabular}


Table 3. Cont.

\begin{tabular}{|c|c|c|c|c|}
\hline Stakeholders & Model Inputs & $\begin{array}{l}\text { Assessment } \\
\text { Level }\end{array}$ & Contribution & Outputs \\
\hline $\begin{array}{l}\text { Environmental } \\
\text { groups }\end{array}$ & $\begin{array}{l}\text { Environmental and cultural } \\
\text { values, flow timing and } \\
\text { requirements, }\end{array}$ & $\begin{array}{l}\text { Micro/Meso/ } \\
\text { Macro }\end{array}$ & $\begin{array}{l}\text { Local/national } \\
\text { knowledge, } \\
\text { awareness, } \\
\text { prioritisation, } \\
\text { range finding, } \\
\text { alternative } \\
\text { pathways, system } \\
\text { sensitivity }\end{array}$ & $\begin{array}{c}\uparrow \text { Knowledge } \\
\uparrow \text { Robustness } \\
\uparrow \text { Accuracy } \\
\uparrow \text { Awareness } \\
\uparrow \text { Inclusiveness } \\
\uparrow \text { Participation } \\
\uparrow \text { Stakeholder } \\
\text { empowerment and } \\
\text { equity } \\
\uparrow \text { Likelihood of } \\
\text { agreement } \\
\downarrow \text { Likelihood of conflict }\end{array}$ \\
\hline Academics & $\begin{array}{l}\text { Flow timing and } \\
\text { requirements }\end{array}$ & Meso/Macro & $\begin{array}{l}\text { Knowledge, } \\
\text { evidence-based } \\
\text { research, range } \\
\text { finding, system } \\
\text { sensitivity }\end{array}$ & $\begin{array}{l}\uparrow \text { Knowledge } \\
\uparrow \text { Accuracy } \\
\uparrow \text { Robustness }\end{array}$ \\
\hline Local industry & Water demands and timing & Micro/Meso & $\begin{array}{l}\text { Local concerns, } \\
\text { knowledge, inputs }\end{array}$ & $\begin{array}{c}\uparrow \text { Knowledge } \\
\uparrow \text { Participation } \\
\uparrow \text { Likelihood of } \\
\text { agreement } \\
\downarrow \text { Likelihood of conflict }\end{array}$ \\
\hline $\begin{array}{l}\text { States/district } \\
\text { officials/regional } \\
\text { basin managers }\end{array}$ & $\begin{array}{l}\text { Current demands, future } \\
\text { demands, water } \\
\text { management strategies }\end{array}$ & Meso & $\begin{array}{l}\text { Facilitating efforts, } \\
\text { coordinating }\end{array}$ & $\begin{array}{c}\uparrow \text { Awareness } \\
\uparrow \text { Inclusiveness } \\
\uparrow \text { Participation } \\
\uparrow \text { Stakeholder } \\
\text { empowerment and } \\
\text { equity } \\
\uparrow \text { Likelihood of } \\
\text { agreement } \\
\downarrow \text { Likelihood of conflict } \\
\downarrow \text { Unintended trade-offs } \\
\text { in water benefits }\end{array}$ \\
\hline $\begin{array}{l}\text { Government } \\
\text { bodies }\end{array}$ & $\begin{array}{l}\text { Current demands, future } \\
\text { demands, water } \\
\text { management strategies }\end{array}$ & Macro/Meso & $\begin{array}{c}\text { Facilitating, } \\
\text { funding, regulation }\end{array}$ & $\begin{array}{c}\uparrow \text { Awareness } \\
\uparrow \text { Inclusiveness } \\
\uparrow \text { Participation } \\
\uparrow \text { Stakeholder } \\
\text { empowerment and } \\
\text { equity } \\
\uparrow \text { Likelihood of } \\
\text { agreement } \\
\downarrow \text { Likelihood of conflict } \\
\downarrow \text { Unintended trade-offs } \\
\text { in water benefits }\end{array}$ \\
\hline $\begin{array}{l}\text { Environmental } \\
\text { peak bodies (i.e., } \\
\text { World Wildlife } \\
\text { Foundation) }\end{array}$ & $\begin{array}{l}\text { Current demands, future } \\
\text { demands, water } \\
\text { management strategies, } \\
\text { environmental and cultural } \\
\text { values, flow timing and } \\
\text { requirements }\end{array}$ & Macro/Meso & $\begin{array}{l}\text { Stakeholder } \\
\text { representation, } \\
\text { communication, } \\
\text { awareness, } \\
\text { prioritisation, } \\
\text { range finding, } \\
\text { alternative } \\
\text { pathways, system } \\
\text { sensitivity }\end{array}$ & $\begin{array}{c}\uparrow \text { Knowledge } \\
\uparrow \text { Robustness } \\
\uparrow \text { Accuracy } \\
\uparrow \text { Awareness } \\
\uparrow \text { Inclusiveness } \\
\uparrow \text { Participation } \\
\uparrow \text { Support } \\
\uparrow \text { Likelihood of } \\
\text { agreement } \\
\downarrow \text { Likelihood of conflict }\end{array}$ \\
\hline $\begin{array}{l}\text { Industry peak } \\
\text { bodies }\end{array}$ & Export demands & Macro/Meso & $\begin{array}{l}\text { Regulation, } \\
\text { communication }\end{array}$ & $\begin{array}{c}\uparrow \text { Awareness } \\
\uparrow \text { Likelihood of } \\
\text { agreement } \\
\downarrow \text { Likelihood of conflict }\end{array}$ \\
\hline
\end{tabular}




\section{Assumptions and Disadvantages of Digital Platforms for Stakeholder Engagement}

There are clear benefits to utilising digital platforms in the stakeholder engagement process. However, there are user assumptions and drawbacks of using technological-based approaches that must be considered. An assumption and disadvantage of using digital tools are that users are expected to be computer literate and have a working internet connection and access to electronic devices. While the world is becoming increasingly technologically connected, the adoption of digital platforms could further the equality gap between traditionally more powerful water users and less powerful sectors such as local farmers. These local farmers could be left out or disadvantaged by the engagement process if digital tools were solely used. Furthermore, in-person contact and interactions between stakeholders during the participatory process can reveal conflicts or issues that are otherwise not visible to water managers and planners. Loss of personal connections could increase the likelihood of conflict and disagreement of water management and development plans. Therefore, digital platforms should not be used as a complete replacement of traditional stakeholder engagement strategies but rather as a tool to compliment them.

\section{Conclusions}

Well-informed water management decisions and policies require effective communication and a shared understanding of the issue at hand between stakeholders. Communication and understanding between stakeholders can be difficult to achieve, especially in transboundary or politically contentious basins. Digital tools that are objective, transparent and cater to a range of abilities can pave the way forward to understanding issues and effective communication between stakeholder groups. Despite the volume of information, data and models that can be provided to stakeholders in regards to water-related issues, supported decisions can be difficult to obtain. In this paper, we demonstrated how our platform can be used to reconcile and channel differing stakeholder views into the one modelling platform by exploring three broad yet common water resource planning issues. Each case study explored interactions approximately between 10 stakeholders with interests at micro/meso or macro scale in the basin. The flexibility in transcending the scales with relative ease while ensuring accuracy and transparency leads to an increase in the overall participation and knowledge. While Basin Futures can be used to engage and collaborate with a variety of stakeholders on water-related issues and projects, it is essential that the process is ground-truthed with local data. The platform can be used to gain creative insights and a better understanding of the issue at hand to build consensus and agreement between stakeholder groups.

Author Contributions: Conceptualisation, J.O., C.P., A.P., A.S. and P.T.; methodology, J.O. and C.P.; software, P.T.; writing-original draft preparation, J.O.; writing-review and editing, J.O., C.P., A.P., A.S. and P.T. All authors have read and agreed to the published version of the manuscript.

Funding: This perspective piece contributes to the Basin Futures project, which is funded by CSIRO Land and Water.

Acknowledgments: We acknowledge the advisory board for Basin Futures. We thank three anonymous reviewers for improvements to the manuscript.

Conflicts of Interest: The authors declare no conflict of interest.

\section{References}

1. Vörösmarty, C.J.; McIntyre, P.B.; Gessner, M.O.; Dudgeon, D.; Prusevich, A.; Green, P.; Glidden, S.; Bunn, S.E.; Sullivan, C.A.; Liermann, C.R. Global threats to human water security and river biodiversity. Nature 2010, 467, 555. [CrossRef] [PubMed]

2. Mekonnen, M.M.; Hoekstra, A.Y. Four billion people facing severe water scarcity. Sci. Adv. 2016, 2, e1500323. [CrossRef] [PubMed]

3. UNESCO World Water Assessment Programme. The United Nations World Water Development Report 2019: Leaving No One Behind; UNESCO: Paris, France, 2019. 
4. FAO. Coping With Water Scarcity: An Action Framework for Agriculture and Food Security; Food and Agriculture Organization of the United Nations: Rome, Italy, 2012.

5. Mancosu, N.; Snyder, R.; Kyriakakis, G.; Spano, D. Water scarcity and future challenges for food production. Water 2015, 7, 975-992. [CrossRef]

6. Rosegrant, M.W.; Ringler, C.; Zhu, T. Water for agriculture: Maintaining food security under growing scarcity. Annu. Rev. Environ. Resour. 2009, 34, 205-222. [CrossRef]

7. Montanari, A.; Young, G.; Savenije, H.; Hughes, D.; Wagener, T.; Ren, L.; Koutsoyiannis, D.; Cudennec, C.; Toth, E.; Grimaldi, S. "Panta Rhei-everything flows": Change in hydrology and society-The IAHS scientific decade 2013-2022. Hydrol. Sci. J. 2013, 58, 1256-1275. [CrossRef]

8. FAO. Coping With Water Scarcity in a Changing Climate; FAO: Rome, Italy, 2018.

9. Vörösmarty, C.J.; Green, P.; Salisbury, J.; Lammers, R.B. Global water resources: Vulnerability from climate change and population growth. Science 2000, 289, 284-288. [CrossRef] [PubMed]

10. Mackay, E.; Wilkinson, M.; Macleod, C.J.; Beven, K.; Percy, B.J.; Macklin, M.; Quinn, P.F.; Stutter, M.; Haygarth, P.M. Digital catchment observatories: A platform for engagement and knowledge exchange between catchment scientists, policy makers, and local communities. Water Resour. Res. 2015, 51, 4815-4822. [CrossRef]

11. Graversgaard, M.; Jacobsen, B.H.; Kjeldsen, C.; Dalgaard, T. Stakeholder Engagement and Knowledge Co-Creation in Water Planning: Can Public Participation Increase Cost-Effectiveness? Water 2017, 9, 191. [CrossRef]

12. Wehn, U.; Collins, K.; Anema, K.; Basco-Carrera, L.; Lerebours, A. Stakeholder engagement in water governance as social learning: Lessons from practice. Water Int. 2018, 43, 34-59. [CrossRef]

13. OECD. Stakeholder Engagement for Inclusive Water Governance; IWA Publishing: London, UK, 2015.

14. Verkerk, P.J.; Sánchez, A.; Libbrecht, S.; Broekman, A.; Bruggeman, A.; Daly-Hassen, H.; Giannakis, E.; Jebari, S.; Kok, K.; Krivograd Klemenčič, A.; et al. A Participatory Approach for Adapting River Basins to Climate Change. Water 2017, 9, 958. [CrossRef]

15. Olsson, J.A.; Andersson, L. Possibilities and problems with the use of models as a communication tool in water resource management. In Integrated Assessment of Water Resources and Global Change; Springer: Dordrecht, The Netherlands, 2006; pp. 97-110.

16. Faulkner, H.; Parker, D.; Green, C.; Beven, K. Developing a Translational Discourse to Communicate Uncertainty in Flood Risk between Science and the Practitioner. AMBIO J. Hum. Environ. 2007, 36, 692-704. [CrossRef]

17. Beven, K.J.; Alcock, R.E. Modelling everything everywhere: A new approach to decision-making for water management under uncertainty. Freshw. Biol. 2012, 57, 124-132. [CrossRef]

18. Hutton, C.; Wagener, T.; Freer, J.; Han, D.; Duffy, C.; Arheimer, B. Most computational hydrology is not reproducible, so is it really science? Water Resour. Res. 2016, 52, 7548-7555. [CrossRef]

19. Emmett, B.; Gurney, R.; McDonald, A.; Ball, L.; Bicak, M.; Blair, G.; Bloomfield, J.; Buytaert, W.; Delve, J.; Yehia, E.; et al. Heads in the cloud: Innovation in data and model dissemination. Int. Innov. 2014, 141, 82-85.

20. Cosgrove, W.J.; Loucks, D.P. Water management: Current and future challenges and research directions. Water Resour. Res. 2015, 51, 4823-4839. [CrossRef]

21. Taylor, P.; Stewart, J.; Rahman, J.; Parashar, A.; Pollino, C.; Podger, G. Basin Futures: Supporting water planning in data poor basins. In Proceedings of the 22nd International Congress on Modelling and Simulation, Hobart, Tasmania, Australia, 3-8 December 2017.

22. Perrin, C.; Michel, C.; Andréassian, V. Improvement of a parsimonious model for streamflow simulation. J. Hydrol. 2003, 279, 275-289. [CrossRef]

23. Frieler, K.; Lange, S.; Piontek, F.; Reyer, C.P.O.; Schewe, J.; Warszawski, L.; Zhao, F.; Chini, L.; Denvil, S.; Emanuel, K.; et al. Assessing the impacts of $1.5^{\circ} \mathrm{C}$ global warming-Simulation protocol of the Inter-Sectoral Impact Model Intercomparison Project (ISIMIP2b). Geosci. Model Dev. 2017, 10, 4321-4345. [CrossRef]

24. Castrogiovanni, E.M.; La Loggia, G.; Noto, L.V. Design storm prediction and hydrologic modeling using a web-GIS approach on a free-software platform. Atmos. Res. 2005, 77, 367-377. [CrossRef]

25. Svatoň, V.; Podhoranyi, M.; Vavřík, R.; Veteška, P.; Szturcová, D.; Vojtek, D.; Martinovič, J.; Vondrák, V. Floreon+: A Web-Based Platform for Flood Prediction, Hydrologic Modelling and Dynamic Data Analysis. In Dynamics in GIscience; Springer: Cham, Switzerland, 2018; pp. 409-422. 
26. McDonald, S.; Mohammed, I.N.; Bolten, J.D.; Pulla, S.; Meechaiya, C.; Markert, A.; Nelson, E.J.; Srinivasan, R.; Lakshmi, V. Web-based decision support system tools: The Soil and Water Assessment Tool Online visualization and analyses (SWATOnline) and NASA earth observation data downloading and reformatting tool (NASAaccess). Environ. Model. Softw. 2019, 120, 104499. [CrossRef]

27. International Network of Basin Organizations. The Handbook for the Participation of Stakeholders and the Civil Society in the Basins of Rivers, Lakes and Aquifers; INBO: Paris, France, 2018.

28. Bruinsma, J. The resource outlook to 2050: By how much do land, water and crop yields need to increase by 2050. In Proceedings of the Technical Meeting of Experts on How to Feed the World in 2050, Rome, Italy, 24-26 June 2009; pp. 24-26.

29. Van Wart, J.; Kersebaum, K.C.; Peng, S.; Milner, M.; Cassman, K.G. Estimating crop yield potential at regional to national scales. Field Crops Res. 2013, 143, 34-43. [CrossRef]

30. Tilman, D.; Balzer, C.; Hill, J.; Befort, B.L. Global food demand and the sustainable intensification of agriculture. Proc. Natl. Acad. Sci. USA 2011, 108, 20260-20264. [CrossRef] [PubMed]

31. Ministry of Agriculture and Livestock. National Agriculture Development Plan 2007-2016; Ministry of Agriculture and Livestock: Port Moresby, Papua New Guinea, 2007.

32. Bunn, S.E.; Arthington, A.H. Basic principles and ecological consequences of altered flow regimes for aquatic biodiversity. Environ. Manag. 2002, 30, 492-507. [CrossRef] [PubMed]

33. Junk, W.J.; Bayley, P.B.; Sparks, R.E. The flood pulse concept in river-floodplain systems. Can. Spec. Publ. Fish. Aquat. Sci. 1989, 106, 110-127.

34. Poff, N.L.; Zimmerman, J.K. Ecological responses to altered flow regimes: A literature review to inform the science and management of environmental flows. Freshw. Biol. 2010, 55, 194-205. [CrossRef]

35. Leendertse, K.; Mitchell, S.; Harlin, J. IWRM and the environment: A view on their interaction and examples where IWRM led to better environmental management in developing countries. Water SA 2008, 34, 691-698. [CrossRef]

36. Sullivan, C. Calculating a Water Poverty Index. World Dev. 2002, 30, 1195-1210. [CrossRef]

37. Norman, A. Water resources sector strategy: Strategic directions for World Bank engagement. J. Econ. Lit. 2004, 42, 981.

38. Butler, C.; Adamowski, J. Empowering marginalized communities in water resources management: Addressing inequitable practices in Participatory Model Building. J. Environ. Manag. 2015, 153, 153-162. [CrossRef]

(C) 2020 by the authors. Licensee MDPI, Basel, Switzerland. This article is an open access article distributed under the terms and conditions of the Creative Commons Attribution (CC BY) license (http://creativecommons.org/licenses/by/4.0/). 